\title{
岐路に立つ抗生物質
}

新薬開発は今のやり方でよいか。

原文：Antibiotics at the crossroads Nature Vol.431(899-902)/21 October 2004;www.naturejpn.com/digest

\section{Carl Nathan}

フレ会の医学的需要を予測し、それを満た 11上すの製薬会社にとって当然のことだ と人々は考えている。抗生物質があれば、いつ でも細菌感染は治療されるものだと思われて いる。それでもなお、感染症は世界全体で第2 位、経済先進国で第3位の死因である。しかし、 細菌が既存薬物に対しての耐性を獲得してい くなかで、製薬産業による抗生物質開発は意 外にも急減速しているのだ(右上のグラフを参 照) $)^{1-3}$ 。この新しい問題は、主として発展途上 国にみられる疾患の治療に用いる抗生物質の 不足という旧来の問題と一体化しつつある。 先進国でみられるようになってきた危機と、 途上国が直面し続けている危機は同じ問題を はらんでいる。原因は経済、規制、および科学 的問題にあり、いずれも抗生物質に対する耐 性という問題が状況を悪化させている。政府 機関と医学界が薬剤耐性の問題に取り組んで はいるが3-6、事態はほとんど変化していない。 抗生物質をめぐる危機は先進国でも途上国で も同じものであるという認識のもと、新たな 取り組みが必要だ。抗生物質の研究開発はい ま、人類の大部分が必要とするレベルを下回 り続け、なお急激に縮小している。そのなかで 我々にいったい何ができるのか。以下、まずは じめに研究開発の縮小原因を考え、次に感染 症と永続的に戦うための建設的取り組みに関 して「理想的」提案を行う。焦点は薬物に当て るが、抗生物質への依存度を下げるためには 予防接種が大きな役割を担っている。

\section{経済的圧力}

利益採算に関していえば、製薬業界ほど、研 究費の多大さから製品開発にかかるプレッ シャーの大きい産業はあまりない。ドル箱を 追求する必要上、企業として慢性疾患の長期 治療薬へ力が注がれ、細菌感染症の短期治療 薬は脇に置かれがちだ7。大手企業が製造して

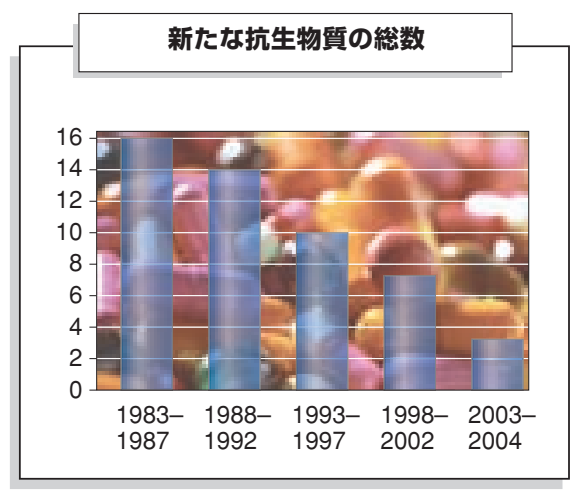

いる抗生物質は、できるだけ多くの患者へ投 与できるようにするため、広い抗菌スペクト ルをもつよう設計されたものが大半である。 これが抗生物質の市場生命を縮めている。つ まり、抗生物質が広く利用されることで耐性 菌の出現が促されるのである。耐性の問題を 回避するため、医師には抗生物質の使用に慎 重になることが求められている。このため、医 薬の世界では収益に限界があり、製薬企業は 抗生物質生産量のおよそ半分を食品産業に振 り向けている 5 。豚肉や鶏肉、魚、乳製品の製 造企業は、動物の健康管理や成長促進のため に抗生物質を使用している。これがやがて耐 性菌が選抜され、人体に入り込むことにつな がり、そうなれば薬効は急速に消失してかつ ては治療可能だった感染症が治療不能なもの 亡なる ${ }^{4-9}$ 。

企業が新たな抗生物質の開発から手を引け ば、実地と理論の両面で抗生物質生物学の專 門技術が失われることにつながる ${ }^{1}$ 。微生物学 の専門家が配置転換されたり退職したりすれ ば、大学も専門家を輩出しなくなる 5 。先進国 で抗生物質研究の再開が求められても、知識 基盤を再構築するには時間がかかることにな るのだ。

\section{ビジネスモデルの見直し}

非営利団体である「結核治療薬開発のための 世界同盟(Global Alliance for Tuberculosis
Drug Development)」は、途上国に多い疾患 のための抗生物質を開発すればそれなりの増 益が見込めることを業界に説けるだけの事例 を築き上げている10。また、アストラゼネ力社 は抗結核薬開発の研究拠点をインドに設立し (www.astrazenecaindia.com)、グラクソ・ス ミスクライン社は結核とマラリアの治療薬 に関する研究チームを創設した(www.gsk. com/financial/reps02/CSR02/GSKcsr-7. $\mathrm{htm})$ 。これらは前向きな一歩ではあるが、途 上国特有の感染症治療の備えとして十分では なく、先進国で細菌感染用の抗生物質が急激 に不足してきたことにも対処できない。

学界の研究者は、感染症の化学生物学に関 する研究を急速に進めている。しかし彼らは、 「ヒット化合物」からリード化合物を作り、リー ド化合物から医薬品を生み出すのに必要な医 薬品化学や薬理学の知識と專門技術を持ち合 わせない。

このような状況には非営利製薬企業という 新たな存在が必要である。リーダーシップは 営利企業がとる。優遇税制によって、研究者や 経営者に交替で休業期間を与えて非営利企業 で働かせるよう業界を仕向ける。製薬業界関 係者には、所属企業そのものでは取り組むこ とのできない活動に個人として貢献すること に喜びを感じる人が少なからずいるだろう。

非営利企業は営利企業とは違う方法で研究 を遂行することができる。特許を取得して知 的財産権を保護することもできるが、知的財 産権は無償とする。そうすれば、患者や社会の 需要に応えるべく製造・販売する医薬品の開 発をほかの企業や団体にさせることによっ て、成果を広く宣伝することも可能である。低 所得者市場向け販売はコストベースで行い ながら、富裕者市場向け販売を従来通り利潤 ベースで行うのがその一例である。

バイオテクノロジー企業は学界の研究者の 発想を医薬品に昇華させ始めているが、特に》 
> 抗生物質開発の専門技術が欠乏している現 在は、中小企業が医薬品化学や薬理学の領域 で世界的な成果を上げるのは困難である。非 営利製薬企業であれば、高所得の国での売り 上げ収益を利用してこうした事業を行い、そ の他の地域では営利を求めない販売を行うと いう使命を果たすことができる。

抗生物質耐性菌の出現を遅らせる最適な方 法として確立されているのは、ひとつ以上の 薬剤と組み合わせて投与する方法、いわゆる 併用療法である。業界が支援する非営利製薬 企業は、効果的な薬物の組み合わせを早い段 階で発見する研究契約を民間企業と結び、そ れを収益源とできるだろう。実際、非営利企 業であれば、同時に阻害することが細菌にと って致命的となる標的(通常は微生物の酵素) の早期発見は知識を共有することで可能とな るという考え方を試すことができる。

非営利企業への資金は、おそらく大部分を 政府または財団に頼らなければならない。優 遇税制によって営利企業には、設備や消耗品、 薬品、臨床試験、それに規制や法律に関する 業務など、実際的便宜を実費で提供するよう に仕向けることができるだろう。製造は低． 中所得国の工場に委託する。

途上国から先進国に薬剤が逆輸入されるな どさまざまな問題も考えられるが、21世紀の 社会が 19 世紀的な感染症死亡率を許容でき るだろうかと問えば、おのずから答えはでる だろう3。

\section{規制の障壁}

新しい抗生物質の開発には、規制上の要求事 項が新薬承認を難しくしているという現行の システムにも大きな問題がある 1,5 。米国では、 新たな抗生物質に関して、薬剤感受性菌によ る感染症の治療で既存の抗生物質亡比べて優 れていることを企業が示さなければならない。 薬剤感受性菌に対して既存の抗生物質はきわ めて効果的であるため、新たな抗生物質に大 きな優位性を見出すことは困難である。さら に、重篤な薬剂耐性菌感染患者では耐性が確 認される以前にほかの抗生物質が投与されて いる場合が多いため、薬剤耐性菌による感染 で新たな抗生物質を試験するのは非常に困難 である。つまり、規制システムは一般的な安全 性と有効性の基準に合わせたものになってお り、抗生物質耐性という特殊な事例を受け入
れる余地をもっていない。承認にあたって差 別的に取り扱われることが確実視される製品 を、企業は開発したがらないのである。

\section{規制の刷新}

米国感染症学会による最近の勧告 ${ }^{3}$ (Nature 10月21日号、892ページ参照)の通り、規制 上の要求事項亡特許の振興策を見直し、製薬 産業に新たな抗生物質の開発を促す必要があ ると考える。新たな抗生物質は 3 種類の試験 に合格すれば承認するべきである。第一に、 感染の重症度に照らして安全性プロファイル が許容範囲であること、第二に、抗生物質感 受性菌感染患者に有効であること、第三に、 感染症治療に利用されている既存の抗生物質 の耐性菌に対して in vitroで有効性を示すこ とである。新たな抗生物質は承認後、承認済 み抗生物質の耐性菌に感染した患者で臨床有 効性を追跡し、その情報は収集すると同時に インターネットで公表することとする。

新たな抗生物質は、併用で投与しない限り、 まもなく耐性菌8が現れる。結核やマラリアな ごのような持続性または再発性の感染症では 長期投与が必要であり、治療に用いようとす る抗生物質には新たな承認前試験の創設が必 要である。製造者は前臨床試験を実施し、当該 疾患の治療に用いられている既存の抗生物質 と新たな抗生物質との相互作用を、種類ごと に評価することとする。この情報と薬物動態 プロファイルを利用して、規制当局は患者の 治療に関する承認後の必要条件を新たに設定 する。第一に、製造者は併用可能な薬剤リスト を明示し、そのなかのひとつ以上が新薬と併 用されること。第二に、製造者は、その組み合 わせで実際に投与が行われた場合の臨床有効 性亡薬剤而性出現状況を追跡することとする。 新奇の標的を対象とする新たな抗生物質の 特許期間については、症例の少ない遺伝病の 治療用に開発された薬剤の特許期間が米国で 延長されているのと同じように取り扱われる べきである2。

さらに、新たな抗生物質はすべて、健康な 動物に対して大規模に投与することを禁止し なければならない。EUではこの禁止が 1998 年に立法化されている。。もしほかの国々が これを強制力のある形で受け入れないのであ れば、たとえば税制処置を行うなどして、身 のあるものになるよう努力すべきである。

\section{立往生する科学}

抗生物質の危機に関して、市場の力と規制上 の要求事項ばかりに責任を求めるのは話を単 純化しすぎだ。別のさらに意外な原因があ る。それは、新たな薬物が真に必要とされて いるときに業界の研究開発で作り出されてき たものが、主として既存抗生物質の改良品で あったということである。ここ数十年、抗生 物質として臨床現場に投入された新奇化合物 はわすかか 2 種類であり、標的が生化学的に新 奇なものは 1 種類にすぎない 1,2,8,9。コンビナ トリアル・ケミストリーと計算生物学を利用し て多大な投資が行われた甲斐もなく、意外に も成果が得られていない。ゲノム分析によっ て病原体には何百もの潜在的標的が発見され ているが、依然として細菌感染の治療で投与 される薬物は、標的酵素が不明なもの以外、ほ とんどが4系統の酵素(タンパク質、核酸、細 胞壁、および葉酸の合成に関与するもの)を標 的とするものばかりなのが実態である8。知識 が蓄積され、手段が改良されているというの に成果がでないのはなぜか。その答えは、か つてきわめてうまく機能していたために定説 のように硬直化してしまった、種々の前提条 件にあると考えられる。知識が急速に豊富に なっていくいま、定説は制約条件となるのだ。

\section{斬新なアプローチ}

タンパク質、核酸、細胞壁および葉酸の合成 を阻害する薬物がこれまで首尾よくいつたか らといって、今後もそれに固執すべき理由は ない。微生物の標的を新たに見出すことが必 要である。まず、合成系を標的とするのでは 対象が限られすぎている。DNAやタンパク質 などの大分子にはライフサイクルがある。介 入点を生成に限る必要はなく、プロセシング や修復、分解も弱点である。このことは、 Mycobacterium tuberculosis のプロテアソー ムを標的亡する研究の根拠亡なっている ${ }^{12} 。$

次に、細菌の中心的代謝(中間代謝、エネル ギ一生成、および微量元素獲得)に関与する諸 酢素も大きな標的群である。さらに、上記と の重複もあるが、病原体が宿主の防御機構に 抵抗するのに用いる諸酵素も標的となる。何 といっても、病原体を退治する化合物の選択 にかけてきた時間は、進化の方が研究者よりも はるかに長く、宿主は武器として活性酸素中間 体や活性窒素中間体、孔形成ペプチドをもっ》 
、ててる。もちろん、微生物が宿主の化学的手 段への対抗としてもつ防御機構もまた、進化 によって強化されてきた。しかし人類は、病 原体の防御機構を作用不能にする抗生物質で 宿主の免疫系を支援することができる ${ }^{12,13 。}$

抗生物質開発の目標は、病原体の生存に必 要な酵素を阻害することである。それらの生 存の場はどこか。従来、どの酵素が必須であ るかを評価する試験は、高度に好気的な富栄 養培地で行われてきた。しかし、病原体が宿主 への感染、特に永続的な感染で遭遇するのは、 そのような in vitro 条件とは大きく異なる厳 しい条件である場合がある。in vivoでは代謝 的適所が(酸素、鉄、pH、炭素源など)さまざ まな点で培地と異なっているばかりでなく、 免疫系が作用して病原体の増殖を抑制し、種 々の分子を破壊する。病原体のなかには、培 地での増殖とは異なる遺伝子を発現してうま く適応するものがある14。したがって、in vivo と in vitro とでは必要となる遺伝子群が異な る9,11,15。要するに、不可欠性とは条件的なも のであり、その不可欠性を決める条件は多様 なのである。たとえば、感染症には、結核など のように、始めに潜伏期(細菌と宿主の反応 の平衡状態)を経るものが多い。現在用いら れている結核治療薬は、培地中では、急速に 増殖する細菌を数時間で全滅させる。しか し、実際の結核患者の治療には連日の併用療 法で $6 \sim 9$ 力月以上を要する。これは、細菌 にとって指数增殖期に不可欠な標的が、潜伏 期や慢性期にはさほど重要でないためと考え られる5。

酵母による系統的研究から、遺伝子の变異 が致命的となるのは別の遺伝子の变異が同時 に起こる場合に限られることが多いとわかっ ている16。これは病原体にも当てはまる。した がって、単独では不可欠でなくとも、組み合 わせれば不可欠となる遺伝子産物が標的とさ れるべきである。たとえば、M. tuberculosis にはイソクエン酸リアーゼをコードする遺伝 子がふたつあり、両者とも脂質代謝に関係す る。このうちの一方ではなく両者を同時に破 壊すると、この細菌はin vivoで急激に減少す る(J.McKinney、私信)。リアーゼをふたつ とも標的とすればよいのである。この考え方 は、科学と規制の取り組み方に根本的な变革 を迫る。まず、抗生物質開発は競争するのでは なく、協力して行わなければならない。非営利
製薬企業であれば、別々の企業が製造する候 補薬剤を用いてそのような取り組み方を追求 することができる。次に、効果的な併用療法 に未承認新薬が用いられる場合、規制当局は あくまで併用の臨床試験結果に基づいてその 組み合わせを承認するべきであって、現在の ような薬剤ごとの承認に限るべきではない。

抗生物質開発の足かせとなっている前提条 件には、病原体の標的と同等のもの（木モ口 グ)が宿主に存在してはならないというもの もある。これは宿主への危害を予防するため だ。しかし、細胞壁合成を除けば、抗生物質が 阻害する標的の多くが宿主にホモログをもっ ており、この前提条件は撤廃するべきである。 現代の構造生物学、計算生物学、および化学 生物学を用いれば、宿主に危害を与えること なく病原体を叮くことのできる化合物が必ず 作り出されるだろう ${ }^{17 。}$

従来型の抗生物質開発が手詰まりとなった のは、新薬にスペクトルの広さを求めている ことも一因である。これによって、標的は種 を超えて病原体間で広く保存されていること が必要亡される。最もよく保存されているサ ブサイト以外は標的とすることができないこ とになり、これが厳しい制約となっている。し かし、抗生物質の特異性が高く、一つひとつ の使用頻度が抑えられれば、医学的にはその 方が好ましく、薬剤の有用性も長続きするよ うになる8。

感染症を(可能な場合に必ず)広域抗生物質 ではなく病原体特異的抗生物質で治療するた めには、迅速、正確、かつ特異的な診断が事前 に必要となる。19世紀的方法のまま診断に時 間がかかる特定の感染症を対象に21世紀の技 術で薬剤を開発するのでは意味がない。PCR、 質量分析、量子ドットの力を借りた免疫測定、 ナノテクノロジー、器械使用そのほかの技術 の進歩を利用して診断法を開発しなければな

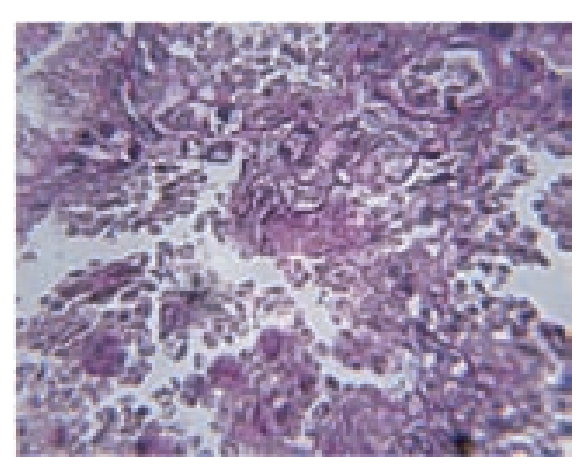

らない。投資をさらに行えば、医師が患者検 体(咽頭スワブや血液、尿など)を検査室に送 り、多くの症例についての診断を数分から数時 間で受け取ることも実現できるだろう。現在、 診断には通常 1 日以上かかる。広域抗生物質 の使用を最小化し、際限のない薬剤耐性との 戦いに対抗し続けるための鍵が治療前診断に あることは認識されなければならない8。

今こそ抗生物質の開発に新技術の投入を始 めるときである。ここに例を 3 点挙げる。ま ず、病原体に関して従来の遺伝子破壊を行つ ても、潜伏期などある特定の感染段階で遺伝 子が果たしている役割は調べることができな い。遺伝子の破壊によってin vitroでの堌殖が 阻害されれば、その遺伝子が欠損した变異株 は全く研究することができない9。ある標的が in vivo で不可欠なものであることを確認する ためには、「条件的な遺伝子の不活化」が必要 である。これは、感染後特定の時間に遺伝子 の機能を停止させるもので、その遺伝子産物 を標的とする抗生物質による感染症治療の効 果がモデル化可能となる。

次に、細菌から単離された酵素ばかりを対 象にした化合物ライブラリのスクリーニング に頼っていてはならない。この方法では、特 定の標的を阻害する化合物が発見されても、 それが菌体内で標的に作用するかどうかはお ろか、病原体の中に侵入するかどうかさえわ からない。自然の状態で菌体内に侵入して標 的を阻害することのできる化合物を直接同 定することが必要である。たとえば、標的を コードする内在性遺伝子を「条件的な低次形 態対立遺伝子」で置換して、標的を消滅させな いまでも減少させる(機能しないようにする) ことが考えられる。そうすれば、「弱体化した」 变異株が特に感受性を示す化合物をライブラ リから見つけ出すことができる9。

3 点目は、革新的な化学を利用すれば、さら に強力な阻害薬が迅速に低コストで発見可能 であるということである。医薬品の開発は、 ナノモル濃度で機能する阻害薬から始められ ることが多い。従来の化合物スクリーニング では、マイクロモルを下回る濃度で活性を示 す阻害薬が得られることはまずない。マイク ロモル濃度の阻害薬の活性を千倍に上げるに は、化学者がチームを組んで何力月もの時間 を費やすことになるかもしれない。しかし、標 的酵素そのものは、結合力が弱く互いに共有》 


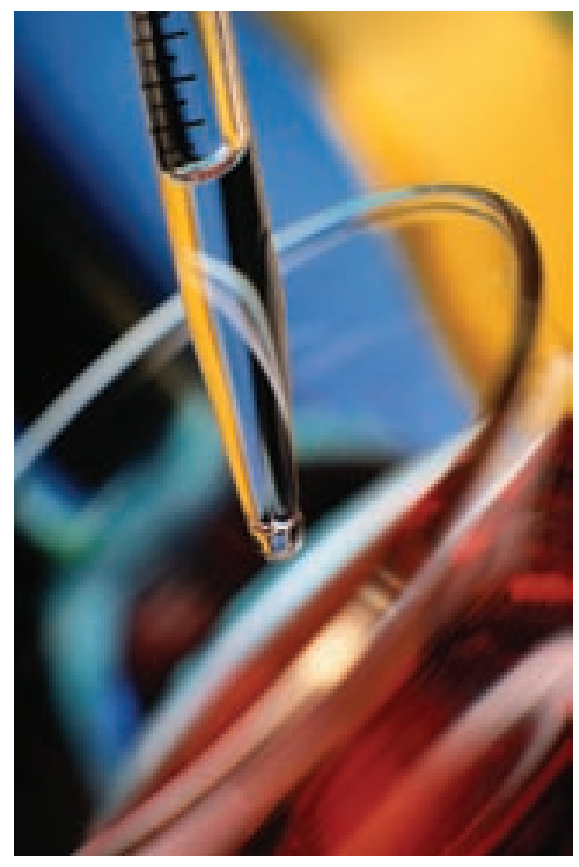

> 結合的に反応する化合物を、別々で相補的な ふたつの化合物ライブラリから選択すること ができる場合がある。さらにその酵素は両化 合物の共有結合形成を触媒し、強い結合力で 酢素を阻害する新たな単一分子が生成するこ ともある ${ }^{18}$ 。

最後に、微生物の多様性をさらに利用する ことも必要である。薬物のリード化合物は、多 くがActinomycetales という単一の細菌目か ら開発された天然物である ${ }^{19}$ 。一方で、微生物 種には培養法が未確立であるものが多いた め、微生物界の大部分は手つかずのままであ る。たとえば、土壤微生物 8,19 之水中微生物、 および微生物を宿主とするウイルス 20 を研究 すれば、ある種が同じ環境中で別の種と競合 するために用いている化合物や酵素が多数発 見される可能性がある。そのような天然物か らは、微生物の弱点やその利用法に関する情 報が豊富に得られよう。

\section{本当に不可能か再考する}

非営利製薬企業に規制の緩い環境で活動さ せ、新たな科学的方法で抗生物質を開発させ るという構想は、絶望的に非現実的なもので あろうか。おそらく、この三本立ての構想で 最も困難な部分は、非営利製薬企業の概念で あろう。しかし、抗感染症薬開発に関しては、 官民共同モデルが少なくとも 3 種類立ち上げ られて進行している21。いずれも対象とする 感染症は単一、または少数に絞られている。各
社が順調に成果を上げている22ことは、市場 から相応の見返りを得ることはできないが社 会に必要とされている事業に民間企業が関与 することが可能であることを示唆している。

ひとつめのモデルは、ビル・アンド・メリン ダ・ゲイツ財団やロックフェラー財団が多額 を出資しているものである。小規模な非営 利製薬企業がこれに含まれ、それぞれ仮想上 のものであって実体は分散している。「マラ リア薬ベンチャー」(Medicines for Malaria Venture；www.mmv.org)は、着想やヒット 化合物、リード化合物を主として大学の研究 者から得、別の大学や製薬企業の研究所の医 薬品化学および薬理学研究に出資する契約方 式を採用している21。「結核治療薬開発のため の世界同盟」(Global Alliance for Tuberculosis Drug Development ; www.tballiance.org) と「等閑疾患治療薬イニシアチブ」(Drugs for Neglected Diseases Initiative; www.dndi. org)でも同じような方法がとられている21。

官民共同モデルのふたつめは、官をパート ナーに大手製薬企業が出資して実地に研究開 発を行うもので、「ノバルティス熱帯病研究 所」(Novartis Institute for Tropical Diseases) がその例である。これにはノバルティス社と シンガポール経済開発庁が共同で出資して いる (www.nitd.novartis.com)。第三のモ デルは、やはりゲイツ財団が多額を出資し ているもので、「ワンワールド保健研究所」 (Institute for OneWorld Health ; www. oneworldhealth.org) が代表例である。こ の研究所は知的財産権の寄付を受けて小規模 な実地の非営利製薬企業を運営し、マラリア、 リーシュマニア症、トリパノソーマ症、蠕虫 感染、および下痢症のワクチンや治療薬を製 造している。最後に、バイオテクノロジー産 業は、ゲイツ財団が出資するイニシアチブに 似た「世界保健のためのバイオベンチャー」 (BIO Ventures for Global Health ; www. bvgh.org)を通じてこの官民共同モデルに貢 献しようとしているようである。

製薬産業を含むあらゆる業界が感染症の 制圧に深く関わっているが、これは医学的理 由ばかりではなく世界の経済開発と安全保 障のためでもある23。上に紹介したようなイ ニシアチブが勢力を大きく広げ、製薬産業が 適切に対処できていない主要な感染症すべて を対象として取り扱うようになることは、先
進国にとっても途上国にとっても有益である ことは間違いない。

筆者のCarl Nathanは、ワイル・コーネル医科大 学微生物免疫学部拉よびコーネル大学ワイル 医科学大学院免疫学分子生物学研究科に所属 している。

1. Projan, S. J. Curr. Opin.Microbiol. 6, 427-430 (2003).

2. Wenzel, R. P. N. Engl. J. Med. 351, 523-526 (2004).

3. Infectious Diseases Society of America. Bad Bugs, No Drugs; www.idsociety.org/

Template.cfm?Section=Home\&CONTENT $\mathrm{ID}=7455 \&$ TEMPLATE=/ContentManagement $/$ ContentDisplay.cfm (2004).

4. Centers for Disease Control and Prevention. A Public Health Action Plan to Combat Antimicrobial Resistance; www.cdc.gov/drugresistance/ actionplan/html/index.htm (2000).

5. Coates, A., Hu, Y., Bax, R. \& Page, C. Nature Rev. Drug Discov. 1,895-910 (2002).

6. World Health Organization Draft Global Strategy for the Containment of Antimicrobial Resistance; www.who.int/emc/amr.html (2001).

7. Service, R. F. Science 303, 1796-1799 (2004).

8. Walsh, C. Nature Rev. Microbiol. 1, 65-70 (2003).

9. Miesel, L., Greene, J. \& Black, T. A. Nature Rev. Genet. 4, 442-456 (2003).

10. Global Alliance for Tuberculosis Drug Development. The Economics of TB Drug Development; www.tballiance.org/7_6D_Publications.asp (2001).

11. Chopra, I., Hodgson, J.,Metcalf, B. \& Poste, G. J. Am.Med. Assoc. 275, 401-403 (1996).

12. Darwin, K. H., Ehrt, S., Gutierrez-Ramos, J. C., Weich, N. \& Nathan, C. F. Science 302, $1963-$ 1966 (2003).

13. Bryk, R., Lima, C. D., Erdjument-Bromage, H., Tempst, P. \& Nathan, C. Science 295, 1073-1077 (2002).

14. Schnappinger, D. et al. J. Exp.Med. 198, 693-704 (2003).

15. Sassetti, C. M., Boyd, D. H. \& Rubin, E. J. Mol. Microbiol. 48,77-84 (2003).

16. Tong, A. H. et al. Science 303, 808-813 (2004).

17. Fidock, D. A., Rosenthal, P. J., Croft, S. L., Brun, R. \& Nwaka, S. Nature Rev. Drug Discov. 3, 509-520 (2004).

18. Manetsch, R. et al. J. Amer. Chem. Soc. 126, 12809 12819(2004).

19. Keller, M. \& Zengler, K. Nature Rev. Microbiol. 2, 141-150 (2004).

20. Liu, J. et al. Nature Biotechnol. 22, 185-191 (2004). 21. Nwaka, S. \& Ridley, R. G. Nature Rev. Drug Discov. 2,919-928 (2003).

22. Vennerstrom, J. L.et al. Nature 430,900-904 (2004).

23. World Health Organization, Commisssion on Macroeconomics and Health Macroeconomics and Health: Investing in Health for Economic Development; www.cmhealth.org (2001).

\section{Acknowledgements}

Thanks to A. Apt, K. Deitsch, H. Djaballah, B. Ganem, W. Jorgensen, T. Kapoor, M.MacCoss, V.Mizrahi, S. Projan, L. Quadri, K. Rhee, M. Rosenberg, D. Russell, D. Scheinberg, D. Schnappinger, D. Tan, T. Templeton and P. van Helden for stimulating discussions. Special thanks are due to P. Davies, S. Ehrt, M. Glickman, B. Kelly, J.McKinney and S. Nwaka. 